DOI: $10.36695 / 2219-5521.2 .2020 .30$

УДК $342.59+342.7$

\title{
P.M. XBAH
}

Руслан Миколайович Хван, здобувач Інституту законодавства Верховної Ради України*

ORCID: 0000-0002-5053-6343

\section{МУНІЦИПАЛЬНА ПОЛІТИКА ДЕРЖАВИ: ОНТОЛОГІЧНІ ТА НОРМАТИВНІ ПІДХОДИ ДО ВИЗНАЧЕННЯ ЕЛЕМЕНТНОГО СКЛАДУ}

Постановка проблеми. Становлення та розвиток в Україні інституту місцевого самоврядування як сфери самоідентифікації, саморегулювання, самодіяльності, самоврядування територіальних громад сукупності жителів відповідних територій держави - села, селища, міста, об'єднаної територіальної громади з вирішення питань місцевого значення (див. ст. 140 Конституції України ${ }^{1}$ ), як самостійного рівня публічної влади - публічної самоврядної (муніципальної) влади (див. ст. 5 Конституції України), а також як однієї із засад конституційного устрою держави - в Україні визнається та гарантується місцеве самоврядування (див. ст. 7 Конституції України), - детермінувало, об'єктивувало та актуалізувало могутні організаційні, управлінські, а також нормативні тенденції щодо формування муніципальної політики держави.

Муніципальна правова політика в доктринальному вимірюванні розглядається як правова політика, що проводиться спільно органами державної влади, органами місцевого самоврядування та населенням муніципальних утворень, тобто жителями-членами територіальних громад, з метою розвитку місцевого самоврядування. Однак необхідно констатувати, що основоположна роль в іiі ініціюванні, становленні, легалізації, розвитку й удосконаленні належить державі. Це детермінується тим, що саме така політика виступає не тільки обов'язковим і невід'ємним специфічним видом державної політики, коли на теренах держави існує і функціонує інститут локальної демократії, а й могутнім організаційно-інструментальним, технологічно-нормативним засобом регламентації, регулювання, легалізації, легітимації, планування і прогнозування розвитку цього важливого соціально-правового інституту, а також державного контролю за його діяльністю. Це особливо важливо в умовах, коли інститут місцевого самоврядування в результаті демократизації суспільного і державного життя отримав статус конституційно-правового інституту, став об'єктом міжнародно-правового регулювання, завдяки його відповідної позитивної регламентації в міжнародному договірному праві, а також проявив себе могутнім засобом модернізації суспільства і держави через безпосередній вплив на формування і інституціоналізацію громадянського суспільства, яке активно розвивається в умовах демократичної правової державності.

Становлення й розвиток муніципальної правової політики, більш того, сам тільки факт їі наявності, означає розробку системного комплексу муніципальних стратегій нормативної властивості, що означають початок процесів становлення, формування і реформування національного законодавства України у сфері місцевого самоврядування та розробку актуальних напрямків супроводження і забезпечення цілеспрямованості та системності здійснюваних державою перетворень у сфері муніципальної реальності. Отже, необхідність і важливість концептуалізації в рамках загальної теорії правової політики наукового знання про муніципально-правову політику, тобто, по-перше, про правову політику саме держави; по-друге, що здійснюється із залученням до неї інших суб'єктів; по-третє, реалізується на муніципальному рівні публічної влади; почетверте, в сфері де в умовах повсякденності функціонують територіальні громади, вирішуючи самостійно або через створювані ними органи екзистенційні питання свого існування в процесі здійснення їх членамижителями свого життєвого циклу, - не викликає сумнівів, особливо враховуючи на вплив такої політики як на стратегію, так і тактику правової модернізації місцевого самоврядування. У контекстуалізації зазначеного представляє особливий науковий і прагматичний інтерес елементний склад такої політики, яка в умовах муніципальної реформи, що проводиться в Україні, виступає методологічним і прогностичним фактором організаційного і нормативного оновлення в сфері локальної демократії.

Аналіз останніх досліджень та публікацій. В умовах становлення та розвитку України як самостійної держави виникає об'єктивна потреба дослідження проблематики не тільки правової політики держави та їі складових елементів, а також елементного складу видових характеристик правової політики держави, зокрема, муніципальної правової політики, що актуалізується не тільки завдяки наявності відповідних кризових явищ у процесах реновації держави і суспільства, а й спробами організаційної, управлінської та нормативної реанімації і модернізації важливих соціально-правових інститутів, до яких належить і місцеве самоврядування.

Необхідно зазначити, що теоретичні засади визначення феноменології правової політики закладено в працях російських правознавців ХІХ ст. С.А. Муромцева, Л.І. Петражицького, Г.Ф. Шершеневича та інших. Разом із тим слід підкреслити, що дослідження такої феноменології в іiї сучасному розумінні, як правова політика саме держави, почались лише на пострадянському просторі і вони пов'язані з науковими працями

(C) P.М. Хван, 2020

${ }^{*}$ Ruslan Hwan, Postgraduate student of Institute of Legislation of the Verchovna Rada of Ukraine 
С.С. Алексєєва, С.А. Комарова, А.П. Коробовової, О.В. Малька, М.І. Матузова, А.С. Перової, І.М. Сенякіна, B.М. Сінюкова та ін.

У вітчизняній правовій науці дослідження правової політики держави чи державної правової політики проводились фрагментарно. Можна назвати вчених-фахівців у сфері теорії права і політології, що в своїх дослідженнях торкалися цієї проблематики, серед них - Л.М. Герасіна, С.М. Гусаров, Н.А. Железняк, М.І. Панов, О.В. Петришин, А.О. Селіванов, В.Я. Тацій, Ю.С. Шемшученко та ін.

Дослідження муніципальної правової політики у вітчизняному правознавстві не проводились зовсім, враховуючи відсутність інституту локальної демократії, який був замінений у радянський період існуванням системи місцевих рад, що на принципах демократичного централізму входили в єдину систему рад та являли собою, за виразом Л.І. Брежнева, «вищі органи державної влади на місцях». Початок профільних досліджень збігся з набуттям Україною державної незалежності, законодавчою, а потім і конституційною легалізацією в суверенній державі інституту місцевого самоврядування та формуванням національної наукової школи муніципального права, представники якої - М.О. Баймуратов, І.П. Бутко, М.І. Корнієнко, М.П. Орзіх, В.Ф. Погорілко, М.О. Пухтинський, В.Ф. Сіренко, Ю.М. Тодика, О.Ф. Фрицький та ін. заклали підвалини для доктринального обгрунтування необхідності розробки та прийняття в державі муніципальної правової політики. Така позиція була посилена науковими працями Б.П. Андресюка, О.В. Батанова, А.С. Бурлаки, І.А. Грицяка, В.М. Кампа, А.А. Коваленка, Т.А. Костецької, В.В. Кравченка, П.М. Любченка, В.М. Оніщука, І.М. Пахомова, О.В. Приєшкіної, Н.І. Рудої, Т.С. Смирнової, А.Ф. Ткачука та ін.

Разом із тим проблематика розробки та втілення муніципальної правової політики в Україні залишається розробленою недостатньо, хоча, враховуючи кризовий стан сучасної державності та нові глобальні виклики подальшому існуванню людства (пандемія на захворювання коронавірусом), що детермінує активізацію, трансформацію та модифікацію задач і функцій не тільки національної держави та всієї міжнародної спільноти держав, а й безпосередньо органів місцевого самоврядування, що опинилися на передньому краї боротьби з хворобою, що охопила жителів-членів територіальних громад, проблематика муніципальної правової політики держави набуває своєї об'єктивізації і якісно нового наповнення, особливо в напрямі вдосконалення загального і конкретного стратегічного управління на індивідуально-колективному, локальному, регіональному, державному, субрегіональному та універсальному рівнях управління в нових умовах існування конкретної людини, її локальних спільнот, регіонів, держав, міжнародної спільноти, людства, що робить дослідження феноменології муніципальної правової політики, іiі ознак, принципів, елементного складу науково і праксеологічно обгрунтованим і актуальним.

Тому метою цієї статті $€$ дослідження онтологічних та нормативних підходів до визначення елементного складу муніципальної правової політики.

Виклад основного матеріалу. Пильна увага публічної державної влади України до всебічної модернізації публічної самоврядної (муніципальної) влади, заснованої на цінностях та інститутах демократії, носить об'єктивний характер, вважаючи на об'єктивну необхідність вдосконалення демократичної правової державності, збереження іiі управлінсько-засадничої парадигми та реалізацію іiї гуманістичного потенціалу. Це також детермінується особливою роллю місцевого самоврядування, що дає суттєві можливості виробити та апробувати нові форми (моделі) взаємодії людини, суспільства, держави, які не тільки є важливими для існування останньої, а й зорієнтовані на створення відповідних умов, що забезпечують гідне життя і вільний розвиток особистості у межах колективної територіальної спільноти - громади.

Треба зазначити, що місцеве самоврядування являє собою особливий суб'єкт для модернізації, який характеризується високим рівнем складності й суперечливості, враховуючи, що цей інститут поєднує в собі публічно-правові та громадські інтереси, має власні цілі, завдання та функції, специфічні способи і форми їх здійснення. Водночас саме в рамках цього інституту формується правовий простір не тільки місцевого самоврядування, а й правовий простір формування і реалізації життєвих намагань, потреб, інтенцій, інтересів, атитюдів індивідуума - жителя-члена територіальної громади, в межах якої він в умовах повсякденності здійснює свій життєвий цикл. Отже, по суті, місцеве самоврядування не тільки виступає відносно самостійною системою організації діяльності населення відповідної території і спеціально оформлених публічновладних установ (органів місцевого самоврядування) щодо вирішення питань місцевого значення, а й формою життедіяльності самої територіальної громади та кожного з її членів.

Звідси, розробка муніципальної правової політики держави в цій сфері виступає як об'єктивно необхідний крок для визначення оптимальної управлінсько-нормативної парадигми розвитку і вдосконалення місцевого самоврядування, а також стратегічного розвитку його нормативно-правового супроводження і забезпечення, з наступною легалізацією на конституційному або законодавчому рівнях. Крім того, і це є стратегічно важливим, саме муніципальна правова політика повинна визначити національну модель місцевого самоврядування, що формується та буде застосованою в державі.

Слід зазначити, що в Україні з метою зміцнення і підвищення дієвості місцевого самоврядування в останні роки здійснено не тільки заходи політичного, економічного та ідеологічного характеру, скільки масштабні перетворення правового регулювання суспільних відносин, що виникають у процесі організації муніципальної влади та вирішення питань місцевого значення, зокрема, розширено сферу та організаційно-правові форми взаємодії між державою та територіальними громадами і сформованими ними органами місцевого самоврядування. Найбільш важливі кроки зроблені владою через процес оптимізації територіальних громад - шляхом створення добровільних об’єднаних громад, а також підвищення спроможності територіальних громад в матеріально-фінансовому відношенні у рамках децентралізації повноважень публічної влади. Але розуміння щодо національної моделі місцевого самоврядування в результаті зроблених сміливих, але недостатніх кроків законодавця немає. 
Разом із тим відчувається відсутність єдиного нормативного документа, що закріплював би системний комплекс стратегічних завдань щодо реформування системи місцевого самоврядування в державі, відповідні етапи набуття територіальними громадами реальної спроможності та процеси щодо підвищення «компетенційної наповненості» повноважень органів місцевого самоврядування реальними правами і обов'язками, що дозволять їм більш ефективно репрезентувати інтереси територіальних громад у контекстуалізації їх вирішення. I тут не йдеться про конституційні новації ${ }^{1}$ або укази голови держави, що час від часу з'являються на виконання стратегічних завдань місцевого розвитку або розробки державної політики ${ }^{2}$, хоча вони відповідним чином формують певні стратегічні заходи, що формують муніципальну правову політику. Однак Україна об'єктивно потребує єдиної і цілісної Концепції муніципальної правової політики, яка буде містити в собі етапи, стадії, стратегічні напрями розвитку та вдосконалення місцевого самоврядування, територіальних громад та всієї системи локальної демократії з вказівкою їх нормативно-правового супроводження $\mathrm{i}$ забезпечення.

Ще раз зважаючи на об'єктивний характер необхідності розробки муніципальної правової політики, у парадигмально-діяльнісному аспекті необхідно наголосити на тому, що неможливо успішно подолати глибокі суперечності й систему негативних відносин у житті держави без науково обгрунтованої і соціально схваленої стратегії подальшого розвитку суспільства, держави і права в конкретних сферах, зокрема в сфері муніципально-правової реальності. Дійсно, необхідною є наявність чітко позначених телеологічних домінант і орієнтирів такого стратегічного курсу розвитку муніципальної влади, основні соціальні, економічні та державно-правові і муніципально-правові параметри й характеристики якої будуть відповідати заявленому в Конституції України суспільно-політичному устрою і ладу. Бо тільки на базі чітко орієнтованого стратегічного курсу руху держави до певного соціально-економічного та державно-правового ладу $є$ можливою i реальною відповідна цілям і задачам цієї стратегії внутрішньо узгоджена, практично значуща $\mathrm{i}$ така, що послідовно реалізується, концепція загальної правової політики держави, в якій особливу і стратегічну роль відіграє муніципальна політика.

Така особлива і стратегічна роль детермінується і визначається насамперед людинорозмірністю цієї політики. Отже, саме вона характеризується безпосередньою антропологізацією та персоналізацією, бо виникає на стику права і соціуму, права і людини, індивідуального і колективного, приватного та публічного, тобто в межах науки про людину і соціум - у межах юридичної антропології ${ }^{3}$ та юридичної персонологї̈4, причому, починаючи з локального, регіонального і державного рівнів та закінчуючи міжнародним (універсальним) рівнем, про що зазначають адепти загальної персонології5.

Виходячи з того, що центром такої політики виступає саме людина, можна стверджувати, що проблематика іiі становлення є однією із центральних і актуальних у сучасному правознавстві, коли в умовах правової глобалізації актуалізуються права людини, що визнаються вищими за права держави. Крім того, муніципальна правова політика має не тільки свою суттєву історичну ретроспективу, що детермінована єдиним можливим, вважаючи на контекстуалізацію особистісної безпеки, спільним проживанням людей у межах спільноти, починаючи 3 первісного суспільства (первісне людське стадо, первісна община), вона також $\epsilon$ пов'язаною зі становленням, розвитком і вдосконаленням основоположних екзистенційно-гуманістичних i екзистенційно-гуманітарних тенденцій в державотворенні і правотворенні, що мають важливе методологічне і праксеологічне значення і в сьогоднішніх державотворчих і правотворчих процесах, знайшло свій наративно-практичний прояв у становленні юридичної антропології.

Муніципальна правова політика є універсальним засобом і соціально-діяльнісним фактором щодо становлення громадянського суспільства в демократичній правовій державі, бо в основі тільки ііі формування, існування і реалізації лежать відносини держави, локального соціуму і людини, що знаходяться як у правовому, так і позаправовому (за межами державно-правового впливу) просторі, коли людина не просто існує i функціонує в межах місцевого самоврядування, а й активно і цілеспрямовано продукує свої екзистенційні інтенції, потреби, устремління, інтереси та демонструє свої атитюди, що можуть бути реалізованими не на рівні абстрактної держави а на рівні конкретної територіальної громади, де держава створила нормативні можливості для такої реалізації через застосування механізмів самопрояву інтересів, їх самоствердження, самодіяльності людини щодо їх визначення і реалізації, самоврядування конкретної особистості, їі груп i макроколективу (громади) в задоволенні своїх екзистенційних інтересів. Саме звідси починаються процеси формування інституцій громадянського суспільства, що безпосередньо задовольняють різнорівневі та поліоб'єктні інтереси конкретної людини, ії груп і асоціацій.

Насамкінець зазначимо, що становлення та розвиток муніципальної правової політики як телеологічно обтяженої і телеологічно обгрунтованої діяльності держави щодо становлення в ній системи місцевого самоврядування, з одночасним вирішенням калейдоскопу питань щодо реальної можливості застосування енергії локальних спільнот з метою їх існування, а також існування самої держави напряму детерміновано зі становленням і розвитком основоположних засад локальної демократії спочатку в рамках національної держави, а потім його вдосконаленням у рамках міждержавної економічної, політичної й правової інтеграції держав, що надає конкретній державності на рівні міжнародної спільноти держав ідентифікацію демократичної і правової.

Звідси можна стверджувати, що муніципальна правова політика за своєю сутністю є системною, комплексною і планомірно обгрунтованою та формалізованою муніципальною стратегією, що робить можливим краще пізнати природу та змістовне наповнення місцевого самоврядування і аксіологічно-екзистенційну цінність територіальної громади як універсальної людської спільноти, де виникає і реалізується життєвий цикл людини. А для належної його організації об'єктивується необхідність стратегічного мислення, стратегічного планування для подальшого розвитку територіальних громад, через усвідомлення важливості фор- 
мування бачення майбутніх пріоритетів місцевого розвитку, встановлення відповідних цілей та завдань для їх досягнення. Але існування муніципальної стратегії розвитку стає можливим лише як результат систематичного процесу локального стратегічного планування, спрямованого як на використання позитивних факторів зовнішніх змінних умов глобалізованого світу, що впливають як на розвиток територіальної громади через інтенсифікацію інтеграційних процесів, так і на одночасну протидію негативним факторам, детермінованим процесами глобалізації (загроза втраті локальної культурної ідентичності, відносної економічної незалежності, місцевих традицій тощо) ${ }^{6}$. Отже, розуміння муніципальної правової політики, як муніципальної стратегії, є можливим тільки при розумінні ії як науково і телеологічно обгрунтованої планомірної, ідеологічно, організаційно, нормативно, ресурсно супроводженої і забезпеченої діяльності уповноважених органів держави та інших суб'єктів, що залучені до їі розробки та реалізації.

Ще один важливий аспект об'єктивізації розробки та наявності муніципальної правової політики в Україні міститься у стійкій і об'єктивній тенденції муніципалізації концепту стійкого (збалансованого) розвитку, який виявляється, визначається і реалізується тільки завдяки своєму локальному існуванню, розташуванню, локально-інструментальній праксеологічній парадигмі та оціночній феноменології. Слід зазначити, що, на думку вітчизняного дослідника В.А. Стрільчука, муніципально-правовий вимір концепції стійкого (збалансованого) розвитку сприяє розширенню, а також переосмисленню окремих аспектів, які стосуються особливостей формування та виразу інтересу в місцевому самоврядуванні ${ }^{7}$. При цьому, як вважає професор М.О. Баймуратов, виявлення та диференціація останнього демонструє та розкриває глибинний філософський, гносеологічний зміст муніципальної влади ${ }^{8}$ У свою чергу, на думку професора О.В. Батанова, саме «інтерес (потреби) жителів - рушійна сила муніципальної влади є надзвичайно важливим компонентом у питаннях організації місцевого самоврядування» 9 , чим власне в котре актуалізує підняте питання. Отже, якщо на перше місце муніципальна правова політика держави ставить концепт стійкого (збалансованого) розвитку її територій, як управлінсько-статутарний вимір своєї ефективності, то муніципалізація такого концепту повинна знайти свою адекватну легалізацію у такій профільній політиці та їі діяльнісно-функціональних характеристиках.

Враховуючи достатньо велику кількість важливих складових муніципальної правової політики, великий науковий інтерес становить їі елементний склад. Вважаємо за потрібне почати його визначення із розкриття елементного складу (елементів) політики, як загальної феноменології, під якими розуміють структурні одиниці політики як єдиної, цілісної системи.

Так, на думку більшості вчених-політологів, до числа елементів політики належать:

1) суб' єкти політики - соціальні спільності (клас, нація, політична еліта, маси, професійні групи), соціальні інститути (парламент, уряд, політичні партії, профспілки, церкви, 3МI, міжнародні організації) і окремі особистості (громадяни, члени політичної еліти, політичні лідери);

2) політична влада - головний елемент політики. Політична влада - це можливість нав'язувати свою політичну волю членам суспільства;

3) політична організація - сукупність державних інститутів, що виражають інтереси особистості, групи, суспільства;

4) політичні відносини - форми взаємозв’язку і взаємодії суб’єктів політики, засновані на згоді, партнерство, конфлікт, панування;

5) політична свідомість - система політичних оцінок, смислів і тверджень, що проявляються на рівні емоцій, почуттів, переживань, симпатій і антипатій (політична психологія), а також на рівні раціональних уявлень, переконань, що становлять політичний світогляд суб'єкта (політична ідеологія);

6) політична культура - тип відносини індивіда, соціальної групи, суспільства в цілому до тих чи інших політичних явищ, подій, фактів, що виявляється в поведінці людей ${ }^{10}$.

Інтерпретація наведених елементів політики у муніципальній контекстуалізації дає нам наступні результати:

1) суб'єкти муніципальної політики - соціальні спільноти (муніципальна політична еліта, муніципальні маси, територіальні громади, об'єднання муніципальних органів), соціальні інститути (парламент, уряд, органи виконавчої влади центральні та на місцях, представницькі органи територіальних громад різних рівнів, їх виконавчі органи, включаючи і об'єднані територіальні громади, органи самоорганізації населення, політичні партії, ЗМІ, міжнародні міжурядові та неурядові організації) і окремі особистості (жителі-члени територіальних громад, члени муніципальної політичної еліти, муніципальні політичні лідери). У результаті здійснення муніципальної реформи в Україні з'явились нові суб'єкти муніципальної політики - об'єднані територіальні громади, їх представницькі органи, старости, у ближній перспективі поява виконавчих комітетів на рівні обласних та районних (повітових) рад (при умові зберігання останніх. - авт.) та в об'єднаних територіальних громадах;

2) муніципальна влада - головний функціонально-владний і компетенційно навантажений елемент муніципальної політики. Муніципальна влада (представницькі та виконавчі органи органів місцевого самоврядування) - це легальна і легітимна можливість роз'яснювати і нав'язувати свою муніципальну волю членам локального суспільства, тобто просувати, формувати, реалізувати ідеологію муніципалізму через дію уповноважених органів місцевого самоврядування в інтересах територіальної громади та 3 метою реалізації питань місцевого значення;

3) муніципальна організація - сукупність державних і самоврядних (муніципальних) інститутів, що виражають інтереси особистості-члена територіальної громади; муніципальної групи в межах громади, що виникає та формується на основі різних кваліфікуючих ознак, які, тим не менш, є пов'язаними з різнорівневими та поліоб'єктними екзистенційними інтересами членів групи; територіальна громада; локальне сус- 
пільство як сукупність жителів-членів громади та їі самоврядних інституцій представницького, виконавчого та громадського характеру;

4) муніципальні відносини - форми взаємозв'язку і взаємодії суб'єктів муніципальної політики колабораційної властивості, що засновані на згоді, партнерстві, співпраці, синергетичній взаємодії, а також на можливому конфлікті, пануванні з можливістю їх вирішення, нівелювання чи нейтралізації на засадах локальної демократії та з застосуванням демократичних процедур;

5) муніципальна свідомість - система муніципальних оцінок, смислів і тверджень, що проявляються на рівні емоцій, почуттів, переживань, симпатій і антипатій жителя-члена територіальної громади, їх груп, всієї територіальної громади, всього локального суспільства (муніципальна психологія - індивідуальна, групова, колективна, локально-універсальна), а також на рівні раціональних уявлень, переконань, що становлять політичний світогляд суб'єкта, задіяного в проєктуванні, розробці, побудові, формуванні, інституціоналізації, реалізації, вдосконаленні, модернізації муніципально-правових відносин (муніципальна ідеологія - індивідуальна, групова, колективна, локально-універсальна, державна, міжнародна);

6) муніципальна культура - складний та інтегративний тип відносин індивіда, соціальної групи, територіальної громади, локального суспільства, державно організованого суспільства, держави, її органів, посадових і службових осіб в цілому, в основі якого лежить пріоритет прав, свобод, обов'язків та інтересів людини-жителя, що є членом територіальної громади, а також інтересів такої громади у їх екзистенційному вимірюванні, - до тих чи інших муніципальних явищ, подій, фактів, що виявляються в поведінці фізичних та юридичних осіб - учасників муніципального життя.

Але існує й інший шлях визначення елементного складу муніципальної правової політики, - через видову характеристику правової політики держави. Так, російський дослідник С.В. Малюгин, досліджуючи теоретичні основи, форми і елементний склад законодавчої політики держави як складової її правової політики, акцентує увагу на елементному складі такої політики, вважаючи, що законодавча політика як вид юридичної (правової) політики, впливаючи на законотворчість (як строго вибудувану правову процедуру), привносить методологічну насиченість у цю діяльність, розвиває і робить ії цілеспрямованою. Зважаючи на це, даний представник доктрини пропоную виокремити в такій політиці відповідні складові елементи ${ }^{11}$ :

- суб'єкт діяльності - насамперед держава в особі їі законодавчих органів, а також апаратів, що володіють правом впливу на законотворчий процес;

- об’єкт діяльності - відповідні суспільні відносини залежно від пріоритетів діяльності, тобто законодавство;

- мета діяльності - аналіз законодавства, приведення його у впорядковану систему, а також створення законодавчого масиву для регулювання нових суспільних відносин;

- засоби діяльності - наукові досягнення (новації в праві), засоби політико-юридичного прогнозування, статистичні методи;

- механізми втілення в реальність даних положень (аналіз, розробка);

- результати і їх оцінка.

Зважаючи на високий рівень технологічної характеристики наведених елементів, що надає їм широкого уніфікаційного потенціалу, вважаємо за можливе інтерпретувати їх у муніципальному контексті, завдяки чому можна визначити наступні складові елементи муніципальної правової політики (через видову характеристику загальної правової політики держави), а саме:

- суб'єкт діяльності муніципальної правової політики - дійсно, первинним суб'єктом муніципальної правової політики виступає насамперед держава в особі їі законодавчих органів, що фактично формують $\mathrm{i}$ легалізують таку політику, а також апарати виконавчих органів держави, що реалізують зазначену політику на практиці; тільки 3 дозволу держави до формування та реалізації такої муніципальної правової політики можуть бути допущенними відповідні суб' єкти та органи, включаючи суб'єктів та органи системи місцевого самоврядування, їх асоціації, а також органи виконавчої влади на місцях, міжнародні організації, що опікуються питаннями локальної демократії;

- об’єкт діяльності муніципальної правової політики - об'єктом муніципальної правової політики виступають специфічні суспільні відносини - муніципально-правові, що виникають між державою, локальним соціумом і територіальною громадою щодо реалізації і захисту прав і свобод, а також законних інтересів людини, екзистенційних інтересів територіальних громад залежно від пріоритетів їх діяльності, що знаходять свою формалізацію у законодавчо-нормативному супроводженні і забезпеченні;

- мета діяльності муніципальної правової політики - це побудова системно впорядкованого управлінсько-організаційного і нормативно-правового комплексу, що забезпечує планування, становлення, розвиток, удосконалення, прогнозування системи місцевого самоврядування в державі, сталий розвиток територіальних громад та набуття ними реальної ресурсної спроможності;

- засоби діяльності муніципальної правової політики - це науково-доктринальні досягнення муніципально-правового будівництва у сфері конституційного, муніципального, адміністративного, фінансового та інших галузей правової науки, що втілені в норми наведених галузей права (новації в праві), засоби політико-юридичного прогнозування, статистичні методи;

- механізми втілення в реальність даних положень муніципальної правової політики - практична реалізація положень муніципальної правової політики через використання методів та принципів державного і муніципального управління, включаючи їх методологічне, законодавчо-нормативне супроводження і забезпечення, з послідовною розробкою нових методів і механізмів, що забезпечують оперативність, оптимальність і високу ефективність муніципального управління, сталий розвиток територіальних громад, набуття ними належної ресурсної спроможності; 
- результати муніципальної правової політики та їх оцінка - формування, побудова національної моделі місцевого самоврядування європейського зразку, її перманентний розвиток та вдосконалення.

Вважаємо, що застосування наведених вище методологічних підходів до визначення елементного складу муніципальної правової політики володіє високим рівнем нормативно-технологічного конструктиву та дає можливість з урахуванням визначених параметральних ознак такого елементного складу побудувати національну муніципальну правову політику Української держави.

Висновки. Резюмуючи, можна дійти наступних висновків:

- наявність і розробка муніципальної правової політики, що в доктринальному вимірюванні виступає як правова політика, що проводиться спільно органами державної влади, органами місцевого самоврядування та населенням муніципальних утворень, тобто жителями-членами територіальних громад, 3 метою розвитку місцевого самоврядування в державі, є об'єктивним обов'язковим та важливим фактором розвитку та вдосконалення демократичної правової державності;

- особлива і стратегічна роль муніципальної правової політики детермінується і визначається насамперед іiі людинорозмірністю. Саме вона характеризується безпосередньою антропологізацією та персоналізацією, бо виникає на стику права і соціуму, права і людини, індивідуального і колективного, приватного та публічного;

- становлення і розвиток муніципальної правової політики означає розробку системного комплексу муніципальних стратегій нормативної властивості, що означають початок процесів становлення, формування і реформування національного законодавства України в сфері місцевого самоврядування та розробку актуальних напрямків супроводження і забезпечення цілеспрямованості та системності здійснюваних державою перетворень в сфері муніципальної реальності;

- муніципальна правова політика за своєю сутністю є системною, комплексною і планомірно обгрунтованою та формалізованою муніципальною стратегією, що дає можливість краще пізнати природу та змістовне наповнення місцевого самоврядування та аксіологічно-екзистенційну цінність територіальної громади як універсальної людської спільноти, у межах якої проходить і здійснюється життєвий цикл людини, а для належної організації такої політики об'єктивується необхідність стратегічного мислення, стратегічного планування як для подальшого розвитку територіальних громад, через усвідомлення важливості формування бачення майбутніх пріоритетів місцевого розвитку, так і встановлення відповідних цілей та завдань для їх досягнення, що включає до себе і визначення елементного складу такої політики;

- визначення елементного складу муніципальної правової політики можливо двома шляхами: або через визначення елементного складу політики як такої, або через визначення елементного складу видової характеристики правової політики (державної, законодавчої тощо);

- визначення елементного складу муніципальної правової політики має велике значення не тільки для визначення аксіології такої політики, воно несе в собі і великий праксеологічний потенціал, бо дає уявлення про структурно-технологічні характеристики такої політики, вплив на які може сприяти їі формуванню, розвитку, вдосконаленню, визначенню стратегічних пріоритетів у процесі її здійснення.

1 Проєкт Закону України «Про внесення змін до Конституції України (щодо децентралізації влади)». URL: https://www.vmr. gov.ua/TransparentCity/Lists/PowerDecentrProject/Default.aspx

2 Див., наприклад: Указ Президента України № 749/2001 від 30 серпня 2001 р. «Про державну підтримку розвитку місцевого самоврядування в Україні»; Указ Президента України № 1276/2005 від 10 червня 2005 р. «Про забезпечення участі громадськості у формуванні та реалізації державної політики»; Указ Президента України від 21 квітня 2015 р. № 224 «Про Раду регіонального розвитку»; Указ Президента України № 545/2016 від 6 грудня 2016 р. «Про першочергові заходи з розвитку місцевого самоврядування в Україні на 2017 рік»; Указ Президента України № 412/2018 від 6 грудня 2018 р. «Про додаткові заходи щодо забезпечення реформ із децентралізації влади»; Указ Президента України № 909/2019 від 18 грудня 2019 р. «Про Раду розвитку громад та територій». URL: https://www.president.gov.ua/documents/5452016-20846

${ }^{3}$ Костогрызов П.И. Юридическая антропология в поисках парадигмы. URL: https://cyberleninka.ru/article/n/yuridicheskayaantropologiya-v-poiskah-paradigmy

4 Петровский В.А., Старовойтенко Е.Б. Наука личности: четыре проекта общей персонологии. Психология. Журнал Высшей школы экономики, 2012. Т. 9. № 1. С. 21-39.

5 Тарасов О.В. Персонативный юридический факт: теоретико-методологическое и международно-правовое измерение. URL: https://cyberleninka.ru/article/n/personativnyy-yuridicheskiy-fakt-teoretiko-metodologicheskoe-i-mezhdunarodno-pravovoeizmerenie-1

${ }^{6}$ Стрільчук В.А. Теоретичні основи розуміння стратегій у муніципальному праві. Вісник Львівського торговельно-економічного університету. Юридичні науки. 2018. Вип. 7. С. 77-84.

7 Стрільчук В.А. Муніципалізація концепту стійкого (збалансованого) розвитку. Правова держава. 2018. № 31. С. 25-30.

8 Баймуратов М.О. Публічна самоврядна (муніципальна) влада в Україні: методологічні підходи до визначення основних ознак. Публічне право. 2011. № 2. С. 4-11.

9 Батанов О.В. Муніципальна влада в Україні: проблеми теорії та практики. Київ, 2010. 656 с.

10 Элементы политики. URL: http://politics.ellib.org.ua/pages-6445.html

11 Малюгин C.B. Законодательная политика государства: теоретические основы, формы и элементный состав. URL: https://cyberleninka.ru/article/n/zakonodatelnaya-politika-gosudarstva-teoreticheskie-osnovy-formy-i-elementnyy-sostav

\section{Резюме}

Хван Р.М. Муніципальна політика держави: онтологічні та нормативні підходи до визначення елементного складу.

Метою цієї статті є дослідження онтологічних та нормативних підходів до визначення елементного складу муніципальної правової політики. Показано, що особлива і стратегічна роль муніципальної правової політики детермінується і визнача- 
ється насамперед ії людинорозмірністю. Саме вона характеризується безпосередньою антропологізацією та персоналізацією, бо виникає на стику права і соціуму, права і людини, індивідуального і колективного, приватного та публічного. Доведено, що визначення елементного складу муніципальної правової політики можливо двома шляхами: або через визначення елементного складу політики як такої, або через визначення елементного складу видової характеристики правової політики (державної, законодавчої тощо). Аргументовано, що визначення елементного складу муніципальної правової політики має велике значення не тільки для визначення аксіології такої політики, воно несе в собі і великий праксеологічний потенціал, бо дає уявлення про структурно-технологічні характеристики такої політики, вплив на які може сприяти ії формуванню, розвитку, вдосконаленню, визначенню стратегічних пріоритетів у процесі ії здійснення.

Ключові слова: правова політика держави, муніципальна правова політика, місцеве самоврядування, територіальна громада, елементи муніципальної правової політики.

\section{Резюме}

Хван Р.Н. Муниципальная политика государства: онтологические и нормативные подходы к определению элементного состава.

Целью этой статьи является исследование онтологических и нормативных подходов к определению элементного состава муниципальной правовой политики. Показано, что особая и стратегическая роль муниципальной правовой политики детерминируется и определяется прежде всего ее человекоразмерностью. Именно она характеризуется непосредственной антропологизацией и персонализацией, поскольку возникает на стыке права и социума, права и человека, индивидуального и коллективного, частного и публичного. Доказано, что определение элементного состава муниципальной правовой политики возможно двумя путями: либо через определение элементного состава политики, как таковой, либо через определение элементного состава видовой характеристики правовой политики (государственной, законодательной и т. д.). Аргументировано, что определение элементного состава муниципальной правовой политики имеет большое значение не только для определения аксиологии такой политики, оно несет в себе и большой праксеологический потенциал, потому что дает представление о структурно-технологических характеристиках такой политики, воздействие на которые может способствовать ее формированию, развитию, совершенствованию, определению стратегических приоритетов в процессе ее осуществления.

Ключевые слова: правовая политика государства, муниципальная правовая политика, местное самоуправление, территориальная громада, элементы муниципальной правовой политики.

\section{Summary}

Ruslan Hwan. Municipal state policy: ontological and normative approaches to determining the elemental composition.

The purpose of this article is to study the ontological and normative approaches to determining the elemental composition of municipal legal policy. It is shown that the special and strategic role of municipal legal policy is determined and determined primarily by its human dimension - it is characterized by direct anthropologization and personalization, because it arises at the junction of law and society, law and man, individual and collective, private and public.

It is pointed out that municipal legal policy is essentially a systematic, comprehensive and systematically grounded and formalized municipal strategy, which makes it possible to better understand the nature and content of local government and the axiological and existential value of the territorial community. the human life cycle is carried out - and for the proper organization of such a policy the need for strategic thinking, strategic planning is objectified - both for further development of territorial communities, through awareness of the importance of forming a vision of future local development priorities and setting appropriate goals and objectives to achieve them , which includes determining the elemental composition of such a policy.

It is proved that the definition of the elemental composition of municipal legal policy is possible in two ways: either by determining the elemental composition of policy as such, or by determining the elemental composition of the species characteristics of legal policy (state, legislative, etc.). It is argued that the definition of the elemental composition of municipal legal policy is of great importance not only for determining the axiology of such policy, it has great praxeological potential, because it gives an idea of the structural and technological characteristics of such policy, the impact of which may contribute to its formation, development, improvement, definition of strategic priorities in the process of its implementation.

Key words: legal policy of the state, municipal legal policy, local self-government, territorial community, elements of municipal legal policy. 